\title{
Population Trend of Grasshopper (Chortjippus Brunneus) and Cabbage Butter Fly (Pieris Brassicae) on Mustard (Brassica (Campestris L.)
}

\author{
Muhammad Umer ${ }^{1 *}$, Noor Muhammad ${ }^{2}$, Muhammad Anwar Khan ${ }^{1}$ and Nisar Uddin ${ }^{2}$ \\ ${ }^{1}$ Department of Plant Protection, University of Agriculture Peshawar, Pakistan \\ ${ }^{2}$ Department of Botany, Hazara University, Pakistan
}

Submission: March 23, 2019; Published: May 16, 2019

*Corresponding author: Muhammad Umer, Department of Plant Protection, The University of Agriculture, Peshawar, Pakistan

\begin{abstract}
Present study was conducted on population dynamics of two insects Grasshopper (Chortjippus brunneus) and Cabbage Butterfly (Pieris brassicae) on mustard (Brassica campestris). The results of weekly mean population showed that the mean population of Pieris brassicae ranged from 0.0 to 1.4 in first week. Among the population maximum attack of caterpillar (1.4) was recorded in treatment 5; whereas no attack of caterpillar was recorded in treatment $1(0.0)$. Second week the attack of caterpillar ranged from 0.3 to 3.0. Among the population maximum attack of caterpillar (3.0) was recorded in treatment 4; whereas the minimum attack of caterpillar was recorded in treatment $2(0.3)$. Third week the attack of caterpillar ranged from 0.0 to 21.7. Among the population maximum attack of caterpillar (21.7) was recorded in treatment 1 ; whereas no attack of caterpillar was recorded in treatment $4(0.0)$. Fourth week the attack of caterpillar ranged from 0.0 to 3.3. Among the population maximum attack of caterpillar (3.33) was recorded in treatment 3 whereas no attack of caterpillar was recorded in treatment $1(0.0)$. While the mean population of grasshopper per plant ranged from 0.7 to 2.0 in first week. Among the population, maximum attack of grasshopper (2.0) was recorded in treatment 2; whereas the minimum attack of grasshopper was recorded in treatment 5 (0.7). Second week the attack of grasshopper ranged from 0.3 to 3.33. Among the population maximum attack of grasshopper $(0.3)$ was recorded in treatment 3 ; whereas the minimum attack of grasshopper was recorded in treatment 4 (3.33). Third week the attack of grasshopper ranged from 0.3 to 3.0 . Among the population maximum attack of grasshopper (0.3) was recorded in treatment 5; whereas the minimum attack of grasshopper was recorded in treatment 1 (3.0). Fourth week the attack of grasshopper ranged from 0.0 to 2.4 and so on whereas no attack of grasshopper was recorded in treatment 3,4 and 7 .
\end{abstract}

Keywords: Population Trend; Grasshopper; Cabbage Butterfly; Mustard plant

\section{Introduction}

Rapeseed commonly known as sarson belongs to the family crucifereae. Among different types, the most common grown in Pakistan are B. campestris, B. napus, B. juncea and Eruca sativa. In General, the rapeseed refers to B. campeastris and B. napus [1] The term rape is derived from the Latin word "rapen" means turnip. The rape seed is obtained from species of Brassica consisting of about 160 species. Many of them have economic importance and all parts of the plant contribute to their usefulness $[2,3]$.

The origin of rapeseed and mustard is not definitely known. Its cultivation has been traced to 2000 B.C in India, China and Japan. Pak-Afghan region, Mediterranean region and the Turko-Iranain region are also its origin places. Brassica seed was first used for oil extraction in India [1]. According to Peolman \& Borthakur
[4] the origin of the different rapes and mustard has been report ed as Asia, Europe and perhaps Africa. Rape and mustard are extensively cultivated in Asia, Japan and Western Europe.

Rapeseed and mustard are annual Rabi crops. It has a tap root system with many roots concentrate in the shallow surface soil and produce usually yellow flowers. Self-pollination is the rule in B. napus but B. campertris is both self and cross pollinated. The fruit is a pod, $5-10 \mathrm{~cm}$ long. Each pod contains 15-40 small round seed of different colors, weighing 4-6 g per thousand seeds [1].

According to Patel \& Dee [5] B. campestris L. tends to a lighter, shorter and more erect growth habit than B. napus L. Its stem height varies considerably with variety from $50-200 \mathrm{~cm}$ (with 80 $150 \mathrm{~cm}$ most common). 


\section{Ecology \& Conservation Science: Open Access}

China is the largest producer of rape and mustard and together with India and Pakistan they grow over 90 percent of the world production [4]. The average yield of this crop depends very much on climate and variety of the crop grown (Holmes, 1984). The highest yield is being obtained in the Netherlands, whereas the average is just over 2.6 tones/ha. While the average yield of rape seed and mustard in Pakistan based on the average of four years (i.e. from 1990-91 to 1993-94) is $745 \mathrm{~kg} / \mathrm{ha}$. The total production of rape and mustard in KP in the year 1993-94 was 14396.2 tones [6]. Weiss [7] stated that rape seed initial use was mainly to produce oil for industry and domestic lighting. Oil has been produced from oil seed rape and other brassica seed crops in Europe since at least the fifteen century and for a much longer period in Asia probably China [8]. Oil is now produced from rape in every continent [9]. Young leaves of rape and mustard are used as vegetable and as fodder. The oil is used in cooking and in making pickles and in industry as lubricant. Since the oil of conventional varieties contains high levels of erucic acid which is injurious to human health; cultivars have been evolved which are low in both erucic acid and glucosinulates which are designated as '00' types [1]. Jourges [10] mentioned that the averages percentage composition of rape is oil (45\%): protein (22\%), carbohydrates (22$25 \%)$, Klason lingnin (5\%), phytic acid (2\%) and glucosinulates (1-4\%). Pathak et al. [11] stated that the B. campestris L. Seed has $46.38 \%$ oil, $17.67 \%$ protein, $6.0 \%$ moisture, $3.74 \%$ ash and $0.46 \%$ allyl-iso-thiocyanate.

Nazir [1] mentioned that the major insect pests of rape and mustard are the painted bug and aphids. Both the adults and nymphs of these insect's suck cell sap from leaves, flowers and pods. Aphid control should be started when the nymph population reaches five per leaf. According to Gould [12]; like many other Brassica, rape falls prey to the infestation of a wide spectrum of insect, from the seedling stage to maturity damaging the crop and result in yield reduction. Srivastava et al. [13] stated that the aphid (L. erysimi) causes considerable damage not only to mustard but also to rape, tori and several other crop species. The incidence of the pest increases with the delayed sowing, while proper sowing time reduces the pest infestation.

The pollen beetles, mustard sawfly, pea leaf miner, flea beetles, seed pod weevils, hairy caterpillar and cabbage butterfly are the most damaging insect pests of the rape crop. Majority of the pests infest the plant reproductive parts. The insects like pea leaf miners which attack the vegetative parts are less damaging and often more easily measurable [14].

The present study was carried out to record the incidence and population density of Grasshopper (Chortjippus brunneus) and cabbage butter fly (Pieris brassicae) on mustard (Brassica campestris L.) crop.

\section{Materials and Methods}

This study was conducted to record the incidence of grasshopper (Chortjippus brunneus) and cabbage butterfly (Pieris brassicae) on mustard crop at the Agricultural Research Institute Tarnab Peshawar, Pakistan in the year 2016 Rabi season.

The mustard variety 'Bulbul 98' was raised on ridges in well prepared soil at Agriculture Research Institute Tarnab, during September 21, 2016. The experiment was conducted in RCBD with three replications and five treatments per replication. The length and width of each experimental unit was 5 and 3 meters, respectively. Each experimental unit was 3 meters apart from other.

The direction of replications was East-West and treatment direction was North-South. Crop germinated on September 21, 2016. The field was visited regularly to the record population density of the concerned insect pest Table 1 .

Table 1: During study the following insect's pest was recorded on mustard crop.

\begin{tabular}{|c|c|c|c|}
\hline Common name & Scientific name & Family & Order \\
\hline Grass hopper & $\begin{array}{c}\text { Chortjippus } \\
\text { brunneus }\end{array}$ & Acrididae & Orthoptera \\
\hline Cabbage butterfly & Pieris brassicae & Pierilidae & Lepidoptera \\
\hline
\end{tabular}

\section{Data Recording}

Common insect pest of mustard crop is Grasshopper and caterpillar which attack on leaves. The data was collected on five randomly selected plants in each experimental unit and averaged over plant i.e. to present data as number of insects per plant.

\section{Results}

The insect pests of mustard other than aphids were recorded from its time of germination till harvest. The mean population of Grasshopper and Caterpillar were recorded on at weekly interval as given in Tables.

\section{Grasshopper}

Table 2: Mean population trend of Grasshopper Chortjippus brunneus per mustard plant during October to December 2016.

\begin{tabular}{|c|c|c|c|c|c|c|c|c|c|}
\hline & & Week 1 & Week 2 & Week 3 & Week 4 & Week 5 & Week 6 & Week 7 & Week 8 \\
\hline \multirow{3}{*}{ T1 } & $\mathrm{R} 1$ & 1 & 1.7 & 3 & 1.3 & 0.3 & 0.7 & 0 & 0 \\
\hline & $\mathrm{R} 2$ & 1 & 1.3 & 0.7 & 1 & 1.7 & 1.7 & 0 & 1 \\
\hline & R3 & 1.7 & 2 & 0.7 & 2 & 1.3 & 0.7 & 0 & 1 \\
\hline \multirow{3}{*}{ T2 } & $\mathrm{R} 1$ & 1 & 1.3 & 0.7 & 0.7 & 1.3 & 1 & 0 & 1 \\
\hline & $\mathrm{R} 2$ & 2 & 1 & 0.7 & 0.3 & 2 & 1 & 0 & 0.3 \\
\hline & R3 & 1.7 & 1.3 & 0.7 & 0.7 & 2.3 & 2.7 & 0 & 0.3 \\
\hline
\end{tabular}




\begin{tabular}{|c|c|c|c|c|c|c|c|c|c|}
\hline \multirow{3}{*}{ T3 } & $\mathrm{R} 1$ & 2 & 0.3 & 1.3 & 1.3 & 1 & 0.7 & 0 & 0.3 \\
\hline & $\mathrm{R} 2$ & 1.3 & 2 & 1.7 & 1 & 1 & 0.6 & 0 & 1.3 \\
\hline & R3 & 1.7 & 2 & 1 & 2.4 & 1.3 & 1.3 & 0 & 1 \\
\hline \multirow{3}{*}{ T4 } & $\mathrm{R} 1$ & 1.7 & 3.3 & 1 & 2 & 1 & 0.7 & 0 & 1.2 \\
\hline & $\mathrm{R} 2$ & 1 & 1 & 0.7 & 1.7 & 0.3 & 2.3 & 0 & 0.7 \\
\hline & R3 & 1 & 1.3 & 0.7 & 0 & 1.3 & 0.7 & 0 & 0.3 \\
\hline \multirow{3}{*}{ T5 } & $\mathrm{R} 1$ & 0.7 & 1.3 & 2.3 & 2.3 & 1 & 1 & 0 & 0.3 \\
\hline & $\mathrm{R} 2$ & 1 & 1.3 & 1 & 1 & 1 & 2.2 & 0 & 0.7 \\
\hline & R3 & 1.3 & 1.3 & 0.3 & 2 & 2 & 2 & 0 & 0.7 \\
\hline
\end{tabular}

Mean population trend of Grasshopper Chortjippus brunneus per mustard plant during October to December 2016 is given in Table 2.

The mean population of grasshopper per plant ranged from 0.7 to 2.0 in first week. Among the population, maximum attack of grasshopper (2.0) was recorded in treatment 2; whereas the minimum attack of grasshopper was recorded in treatment 5 (0.7). Second week the attack of grasshopper ranged from 0.3 to 3.33 . Among the population maximum attack of grasshopper (0.3) was recorded in treatment 3; whereas the minimum attack of grasshopper was recorded in treatment 4 (3.33). Third week the attack of grasshopper ranged from 0.3 to 3.0. Among the population maximum attack of grasshopper (0.3) was recorded in treatment 5 ; whereas the minimum attack of grasshopper was recorded in treatment 1 (3.0). Fourth week the attack of grasshopper ranged from 0.0 to 2.4. Among the population maximum attack of grasshopper (2.4) was recorded in treatment 3; whereas no attack of grasshopper was recorded in treatment 4 (0.0). Fifth week the attack of grasshopper ranged from 0.3 to 2.3. Among the population maximum attack of grasshopper (2.3) was recorded in treatment 2; whereas no attack of grasshopper was recorded in treatment 4 (0.3). Sixth week the attack of grasshopper ranged from 0.6 to 2.3 . Among the population maximum attack of grasshopper (2.3) was recorded in treatment 4; whereas no attack of grasshopper was recorded in treatment $3(0.6)$. Seventh week no attack of grasshopper was found on mustard crop. Eighth week the attack of grasshopper ranged from 0.0 to 1.3. Among the population maximum attack of grasshopper (1.3) was recorded in treatment 3; whereas no attack of grasshopper was recorded in treatment 1 (0.0).

\section{Caterpillar}

Mean population trend of cabbage butterfly Pieris brassicae per mustard plant during October to December 2016 is given in Table 3.

Table 3: Mean population trend of Cabbage butterfly Pieris brassicae per mustard plant during October to December 2016.

\begin{tabular}{|c|c|c|c|c|c|c|c|c|c|}
\hline & & Week 1 & Week 2 & Week 3 & Week 4 & Week 5 & Week 6 & Week 7 & Week 8 \\
\hline \multirow{3}{*}{ T1 } & R1 & 0 & 1.3 & 21.7 & 0 & 2.3 & 1.7 & 0 & 0.7 \\
\hline & $\mathrm{R} 2$ & 0.7 & 0.7 & 0.7 & 1.3 & 1 & 3.3 & 0 & 0.3 \\
\hline & R3 & 0.3 & 1.7 & 1.7 & 2 & 2.7 & 2 & 0 & 1.7 \\
\hline \multirow{3}{*}{ T2 } & R1 & 0.3 & 0.3 & 0.3 & 1.3 & 0.7 & 1.3 & 0 & 0 \\
\hline & $\mathrm{R} 2$ & 0.3 & 2.9 & 1 & 0.3 & 1.7 & 0.3 & 0 & 1.7 \\
\hline & R3 & 0.3 & 1.3 & 0.7 & 0.7 & 1.7 & 2.3 & 0 & 0.7 \\
\hline \multirow{3}{*}{ T3 } & $\mathrm{R} 1$ & 0.3 & 1 & 1 & 1 & 1 & 1.7 & 0 & 0.7 \\
\hline & $\mathrm{R} 2$ & 1.3 & 1.7 & 1.3 & 3.3 & 2.3 & 1.3 & 0 & 0.3 \\
\hline & R3 & 1.3 & 1.7 & 1 & 0.3 & 3.3 & 0.2 & 0 & 0 \\
\hline \multirow{3}{*}{$\mathrm{T} 4$} & $\mathrm{R} 1$ & 1 & 1.7 & 1 & 2 & 0.3 & 1.3 & 0 & 0.3 \\
\hline & $\mathrm{R} 2$ & 0.3 & 3 & 1.3 & 3 & 1 & 1.7 & 0 & 2 \\
\hline & R3 & 1 & 1.7 & 0 & 1 & 1 & 1.7 & 0 & 0.3 \\
\hline \multirow{3}{*}{ T5 } & R1 & 1.4 & 2 & 1.7 & 1.7 & 1.3 & 2 & 0 & 0.3 \\
\hline & $\mathrm{R} 2$ & 0.3 & 2.7 & 1.7 & 0.7 & 1.3 & 1 & 0 & 0.3 \\
\hline & R3 & 0.3 & 2 & 1.3 & 1.7 & 1.3 & 1.7 & 0 & 0.3 \\
\hline
\end{tabular}

The mean population of Pieris brassicae ranged from 0.0 to 1.4 in first week. Among the population maximum attack of caterpillar (1.4) was recorded in treatment 5; whereas no attack of caterpillar was recorded in treatment $1(0.0)$. Second week the attack of caterpillar ranged from 0.3 to 3.0 . Among the population maximum attack of caterpillar (3.0) was recorded in treat- 


\section{Ecology \& Conservation Science: Open Access}

ment 4; whereas the minimum attack of caterpillar was recorded in treatment 2 (0.3). Third week the attack of caterpillar ranged from 0.0 to 21.7. Among the population maximum attack of caterpillar (21.7) was recorded in treatment 1 ; whereas no attack of caterpillar was recorded in treatment $4(0.0)$. Fourth week the attack of caterpillar ranged from 0.0 to 3.3. Among the population maximum attack of caterpillar (3.33) was recorded in treatment 3 whereas no attack of caterpillar was recorded in treatment 1 $(0.0)$. Fifth week the attack of caterpillar ranged from 0.3 to 2.7 . Among the population maximum attack of caterpillar (2.7) was recorded in treatment 1 ; whereas the minimum attack of caterpillar was recorded in treatment 3 (0.3). Sixth week the attack of caterpillar ranged from 0.2 to 3.3. Among the population maximum attack of caterpillar (3.3) was recorded in treatment 1; whereas the minimum attack of caterpillar was recorded in treatment 3 (0.2). Seventh week no attack of caterpillar was found on mustard crop. Eight week the attack of caterpillar ranged from 0.0 to 2.0. Among the population maximum attack of caterpillar (2.0) was recorded in treatment 4 whereas no attack of caterpillar was recorded in treatment $3(0.0)$.

\section{Discussion}

Promptly growing population and alterations in dietary habits linked with urbanization increased the demands for food and fuel. Pakistan has become world's third largest edible oil importer. Edible oil seed crops of Pakistan are classified as conventional (rapeseed, mustard, sesame, groundnut), non-conventional (sunflower, safflower, soybean) and non-true oilseeds (cotton, maize and rice bran) [15].Oil seed mustard (Brassica compestris L.), has become one of the most important oil crops in the country. Conventional mustard varieties impose health concerns due to the presence of erucic acid in oil and glucosinolate in meal. Canola has the advantage over other vegetable oils because it contains lowest content of saturated fatty acids and moderate content of poly-unsaturated fatty acids [16]. In Pakistan, the farmers associated with brassica crops face a lot of problems from insect pests, particularly whitefly, thrips, aphid, painted bug, Grasshopper and Cabbage Butter Fly. The control of pest insects has relied heavily on chemical insecticides which are often overused or misused. The beneficial species, such as parasites and predators are used to control pest insects that established a solid foundation for environmentally safe system for brassica growing farmers [17].

Among different insect pests attacking mustard, the Grasshopper (Chortjippus brunneus) and Cabbage Butter Fly (Pieris brassicae) are the most serious and destructive pest and major limiting factor for mustard cultivation [18] The rate of reproduction varies from 5 to 9 Youngs in a single day by a single female and the total number of Youngs produced by the female varies from 76 to 188 [18]. In current study the mean population of Pieris brassicae ranged from 0.0 to 1.4 in first week. Among the population maximum attack of caterpillar (1.4) was recorded in treatment 5 ; whereas no attack of caterpillar was recorded in treatment 1 (0.0). Second week the attack of caterpillar ranged from 0.3 to 3.0. Among the population maximum attack of caterpillar (3.0) was recorded in treatment 4 ; whereas the minimum attack of caterpillar was recorded in treatment 2 (0.3). Third week the attack of caterpillar ranged from 0.0 to 21.7 [18-30]. Among the population maximum attack of caterpillar (21.7) was recorded in treatment 1 ; whereas no attack of caterpillar was recorded in treatment 4 (0.0). Fourth week the attack of caterpillar ranged from 0.0 to 3.3. Among the population maximum attack of caterpillar (3.33) was recorded in treatment 3 whereas no attack of caterpillar was recorded in treatment $1(0.0)$. While the mean population of grasshopper per plant ranged from 0.7 to 2.0 in first week. Among the population, maximum attack of grasshopper (2.0) was recorded in treatment 2; whereas the minimum attack of grasshopper was recorded in treatment 5 (0.7). Second week the attack of grasshopper ranged from 0.3 to 3.33 . Among the population maximum attack of grasshopper (0.3) was recorded in treatment 3; whereas the minimum attack of grasshopper was recorded in treatment 4 (3.33). Third week the attack of grasshopper ranged from 0.3 to 3.0. Among the population maximum attack of grasshopper (0.3) was recorded in treatment 5; whereas the minimum attack of grasshopper was recorded in treatment 1 (3.0). Fourth week the attack of grasshopper ranged from 0.0 to 2.4 and so on whereas no attack of grasshopper was recorded in treatment 3, 4 and 7 [31-47].

\section{Conclusion}

The results of weekly mean population presented that the mean population of Pieris brassicae ranged from 0.0 to 1.4 in first week. Among the population maximum attack of caterpillar (1.4) was recorded in treatment 5 ; whereas no attack of caterpillar was recorded in treatment $1(0.0)$. Second week the attack of caterpillar ranged from 0.3 to 3.0. Among the population maximum attack of caterpillar (3.0) was recorded in treatment 4; whereas the minimum attack of caterpillar was recorded in treatment 2 (0.3). Third week the attack of caterpillar ranged from 0.0 to 21.7. Among the population maximum attack of caterpillar (21.7) was recorded in treatment 1 ; whereas no attack of caterpillar was recorded in treatment $4(0.0)$. Fourth week the attack of caterpillar ranged from 0.0 to 3.3. Among the population maximum attack of caterpillar (3.33) was recorded in treatment 3 whereas no attack of caterpillar was recorded in treatment $1(0.0)$. While the mean population of grasshopper per plant ranged from 0.7 to $2.0 \mathrm{in}$ first week. Among the population, maximum attack of grasshopper (2.0) was recorded in treatment 2; whereas the minimum attack of grasshopper was recorded in treatment 5 (0.7). Second week the attack of grasshopper ranged from 0.3 to 3.33 . Among the population maximum attack of grasshopper (0.3) was recorded in treatment 3; whereas the minimum attack of grasshopper was recorded in treatment 4 (3.33). Third week the attack of grasshopper ranged from 0.3 to 3.0. Among the population maximum attack of grasshopper (0.3) was recorded in treatment 5; whereas the minimum attack of grasshopper was recorded in treatment 1 (3.0). Fourth week the attack of grasshopper ranged from 0.0 to 2.4 and so on whereas no attack of grasshopper was recorded in treatment 3,4 and 7 . 


\section{Ecology \& Conservation Science: Open Access}

\section{Acknowledgement}

Authors are thankful to Agricultural Research Institute Tarnab Peshawar for providing field for this research work.

\section{References}

1. Nazir S (1994) Crop production. National Book Foundation Islamabad, p. 534 .

2. Sharapov NI (1956) New oil yielding plants population Academy of Science. Moscow USSR: pp. 137-141.

3. Harberd DJ (1972) A contribuation to the cytotaxonomy of Brassica and its allis. Jour Bot Sci 65(1): 1-23.

4. Peolman JM, Borthakur D (1984) Breeding Asian Field Crops. pp. 385.

5. Patel BB, Dee R (1978) Study on the effect of nitrogen, row spacing and anti transpirants on rape seed (B.campestris) grown under fryland condiation. Jour Agri Science 91(2): 257-264.

6. Anonymous (1994) Agricultural Statistics of Pakistan (1993-94). Govt: of paki., Min of food agri. And Livestock, Economic Wing, Islamabad.

7. Weiss EA (1983) Oil seed crops. British library Cataloging in publication data, pp. 61-215.

8. Fussel GE (1955) History of cole (Brasssica Spp.). Nature, London 17(6): 48-51.

9. Holmes MRJ (1980) Nutrition of the oil seed rape crop. Applied Science Publishers Ltd, London, pp. 5-13.

10. Jourges VK (1978) Glucosinloates in the growing and flowering plants of Brassica napus and Brassica campestris. Proc. $5^{\text {th }}$ Int. Rape conf. malmo Sweden, pp. 57-60.

11. Pathak RK, Sharma MK, Tripath RD (1973) Quality study in some cruciferous oil seeds. Indian Jour Agri Res 7(2): 99-103.

12. Gould HJ (1975) Survey of pest incidence on oil seed rape in south central England. Jour An Appl Bio 79(1): 19-26.

13. Sarivastava HC, Bharkaran S, Vatsya B, Menon KKG (1984) Oil seed production constraints and opportunities. Oxford and IBH Pub Pvt. Ltd, pp. 12-128.

14. Free JHR, Wiltiems IJ (1978) A survey of damage caused to crops of oil seed rape (Brassica napus) by insect pest in south central England, and their effect on seed yield. Jour Agri Sci 90: 417-424.

15. Schung E, Hanekluas S (1988) Theoretical principles for the indirect determination of the total glucosinolates content in the rapeseed meal quantifying the sulfur concentration via X-ray florescence (XRF method). J Sci Food Agric 45(3): 243-254.

16. Miri HR (2007) Morpho physiological basis of variation in rapeseed (Brassica napus L.) Yield. Inter J Agric Biol 9: 701-706.

17. Naqvi KM, Kanzada AG, Abbasi FD (1975) Field evaluation of systematic insecticides, their comparative efficacy against potato sucking insect pest. Sindh J Agric Res 10: 7-14.

18. Sharma JC, Joshi FL (1972) Efficiency of different insecticides against mustard aphid (L. erysimi) Rev Appl Ent 65(9): 987.

19. Abbott SW (1925) A method of computing the effectiveness of insecticide. J Econ Entomology 18(2): 265-267.

20. Anonymous (1993) Population dynamics of major insect pests of mustard. Annual progress report for year 1993-93. Agri. Res. Inst. Tarnab, Peshawar, p. 123.

21. Atwal AS, Chaudhary JP, Ramzan M (1987) Mortality factors in the natural population of aphid, Lipaphis erysimi in relation to predators and weather conditions. Rev App Ent A 63(2): 141.
22. Begum M., Hussain M, Talukder FA (1991) Check the Relative effectiveness of some granular insecticides against mustard aphid $L$. erysimi. Jour Bangladesh Agri Sci 18 (1): 49-52.

23. Brar KS, Sandhu GS (1976) Comparison of methods of application for soil systemic granules for the control of mustard aphid. Rev Appl Ent A 65(1):138.

24. Brar KS, Sandhu GS (1978) Laboratory tests for the evaluation of resistant varieties of indian mustard to the attack of aphid. Rev Appl Ent A 63(9):113.

25. Ganguli RN, Roy DR (1976) Studies on the economic preventive spray control Schedule of mustard aphid (L.erysimi) in Tripura. Rev Appl Ent A 65(11): 16-53.

26. Harvir S, Rohilla HR, Ram P, Ahlawat DS, Singh H (1993) Outbreak of painted bug on oilseeds brassica in India. Intern Journ Tropical Agri 11(2): 153-154.

27. Islam DN, Bhuiyah MIM (1990) Field evaluation of failure of insecticide for the control of the mustard (L.erysimi). Jour Bangladesh. Zoo 18(2): 188.

28. Israr M (1986) Varietal preference and chemical control of Brassica aphids brassica .M Sc Thesis Ent Agri Univ Faislabad: 58pp.

29. Jagdev Singh Kular, Sarwan Kumar (2011) Quantification of Avoidable Yield Losses In Oilseed Brassica Caused By Insect Pests. Punjab Agricultural University Ludhiana India Journal of plant protection research 51(1): 38-43.

30. Kabir KH, Mia MD (1987) Effectiveness of some indigenous materials as repellent against the mustard aphid (L.erysimi). Rev Appl Ent A 76(7-12): 69 .

31. Hasan MR, Ahmad M, Rahman MH, Haque MA (2009) Aphid incidence and its correlation with different environmental factorsJ Bangladesh Agril Univ 7(1): 15-18.

32. Mehran KL (1968) History and Ethno boany of mustard in India. Advancing Frontiers of plant Science 19(1): 51-59.

33. Nath DK (1975) Control of mustard aphid (L.erysimi) by soil application of insecticides. Rev Appl Ent A 65(4):556.

34. Nath DK, Sen B (1975) Some observation of Aphidophagus coccinellid beetles in mustard cultivation. Rev Appl Ent A 65(9): 13-43.

35. Patel NM, BD Ghule, VS Dhumal, Deokar AB (1992) Critical time and frequency of insecticidal sprays for the control of groundnut sucking pests. Jour Mahar Agri Uni 17(3): 477-478.

36. Patel SP, Pokharkar RN (1982) Some new records of insect pests infesting cruciferous vegetable crops in Moharastra State. Rev Appl Ent A 70(7):495.

37. Sachan GC, Schan SK (1987) Honeydew excretion by L. erysimi as a criterion for assessing susceptibility in Brassica. Rev Appl Ent A 65(9): 987.

38. Sankarsan R, Amit KG, Bulganin M, Anup D (2014) Diversity, foraging activities of the insect visitors of Mustard (Brassica juncea Linnaeus) and their role in pollination in West Bengal. Journal of Zoology Studies $1(2): 7-12$.

39. Sharma KC, Khatri NK (1986) Study on biology to control of the mustard aphid (L.erysimi) on mustard at khulmattar Rev Appl EntA 65(10): 1706.

40. Singh HV, Verma ND (1976) Brassica campestris as a new host for Hellula undalis, Family Pyralidae. Rev Appl Ent A 65(3): 400.

41. Singh R, Malhothra RK (1984) Relative toxicity of some insecticides as contact poisons to the mustard aphid (L. erysimi). Rev Appl Ent A 65(10): 1706. 
42. Solangi MA, Talpur MA, Hussan T, Baloch HB, Rustamani MA, et al (1994) Field evaluation of different insecticides for the control of Aphid s cracivora on lentil crop. Proceedings of Pakistan Congress of Zool 12(8): 553-556.

43. Srivasta AS, Srivasta JL (1987) Forecasting aphids, painted bug and saw fly on mustard Crop. Rev Appl Ent A 64(1): 113.

44. Upadhyay S, Agrawal RK (1993) Persistant toxicity of some insecticides against (L.erysimi) on mustard. India Jour Plant Protec 21(1): 104-105
45. Upadhyay S, Agrawal RK (1993) Efficacy of different insecticides on incidence of mustard aphid (L.erysimi) and its economics. India Jour Agri Sci 63(8): 522-525.

46. Upadhyay S, Agrawal RK, Kambalkar VS, Nigam KB (1992) Sreening of India mustard varieties resistant to mustard aphid (L.erysimi) in infested and protected environments. Rev Agri Ent A 81(10): 11-40.

47. Zaman M (1990) Evaluation of emulsifiable concentrate insecticides against mustard aphid on rape and mustard. Jour Sarhad Agric (4): 399-402.

\section{Your next submission with Juniper Publishers will reach you the below assets}

- Quality Editorial service

- Swift Peer Review

- Reprints availability

- E-prints Service

- Manuscript Podcast for convenient understanding

- Global attainment for your research

- Manuscript accessibility in different formats ( Pdf, E-pub, Full Text, Audio)

- Unceasing customer service

Track the below URL for one-step submission https://juniperpublishers.com/online-submission.php 